\title{
EU funding state for improving the quality of higher education in Bulgaria
}

\author{
Sevdalina Hristova $^{1 *}$ \\ ${ }^{1}$ Business, Investments, Real Estates Department, Faculty of Economics, University of Economics - \\ Varna, Bulgaria
}

\begin{abstract}
The quality of higher education is one of the critical factors for increasing the competitiveness of the Bulgarian economy and the development of the regions. The financing of the higher education system is one of the main factors for the quality of the provided educational service in higher schools, which is dwelled upon in the Strategy for Development of Higher Education. The aim of the author is to explore the possibilities for using European funding for projects of higher education institutions under the operational programs and on this basis to outline some guidelines for improving the effectiveness of project funding in the sector and enhancing the quality of higher education. In order to determine the role of project funding under the operational programs for improving the quality of higher education in Bulgaria, interviews with experts have been conducted. The results of the research are processed by content analysis and are summarized in the paper. They are the basis of the main conclusions and recommendations for improving the quality of education in Bulgaria.
\end{abstract}

\section{Introduction}

The quality of higher education is one of the critical factors for increasing the competitiveness of the Bulgarian economy and the development of the regions. The human factor plays one of the leading roles in the implementation of innovations. It develops through the accumulated knowledge, which should be improved depending on the specific needs of business and society. Educational institutions, which are called upon to provide well-trained staff, have a key role to play $[1,2]$.

The interrelation of education with a number of socio-economic aspects of life is indisputable. To assess the quality of higher education, various university ranking systems are used, providing an opportunity to assess the quality of the educational service they offer. Each system includes a set of criteria with different weights. The most frequently used criteria can be summarized in the following areas: training, learning environment, research, prestige, employment opportunities, social commitment, knowledge transfer and innovation, internationalization [3].

In their study Petkov, Nedyalkova and Boeva [3] dwell on the six elements of the quality of education through which it can be improved: wider application of distance

* Corresponding author: $\underline{\text { s.hristova@ue-varna.bg }}$ 
learning and e-learning; focus on innovation and knowledge transfer to business; strengthening the relationship with various business and non-profit organizations; practical orientation in the use of ICT, etc. In order to implement these elements in practice, activities and measures of different scope are needed, requiring appropriate funding that can be provided from the higher education institutions (HEI) budgets, but only if the academic council adopts a budget that includes the necessary funds in the relevant items of its expenditure part [4]. For the implementation of the various interventions needed to improve the quality of education, HEIs cannot rely on their income from business activities, which are also insufficient and relatively limited [5]. That is why grants are used under programs funded by EU funds.

The aim of the author is to explore the possibilities for using European funding for projects of higher education institutions under the operational programs and on this basis to outline some guidelines for improving the effectiveness of project funding in the sector and improving the quality of higher education.

In order to determine the role of project funding within the operational programs for improving the quality of higher education in Bulgaria, an interview with experts has been conducted. The results of the research have been processed through content analysis and are the basis of the main conclusions and recommendations for improving the quality of education in Bulgaria.

\section{Quality and financing of higher education}

Higher education across Europe is faced with a number of challenges and a difficult financial situation [6]. This holds true also for the Bulgarian HEIs. Marsikova и Urbanek [7] pose the question whether the state should allocate more funds and invest them in higher education because of its importance for the development of human resources, which in turn are one of the important factors for economic growth. In their monograph, they present arguments and prove this connection, referring to research by other authors. The development of higher education is directly related to the financing of the costs of training, research and innovation [8]. On the other hand, as Vutsova and Arabadjieva point out, "a major problem for achieving high quality is the contradiction arising from linking the subsidy provided to the number of students enrolled, which causes universities to lower their requirements for students in order to preserve their numbers" [9]. In recent years, the funding system has undergone some changes in the direction of reducing dependence on the number of students and strengthening the role of various quality indicators.

Improving the quality of higher education is one of the specific objectives set out in the Strategy for the development of higher education for the period 2014-2020 [10], and the financing of the system is indicated as one of the main factors for the level of quality of the provided educational service in higher schools. The new Strategy for the Development of Higher Education 2021-2030 also includes improving the quality and ensuring financial sustainability and financial incentives for quality education and scientific research as priority areas [11].

Enhancing the quality of educational services results in improving the competitiveness of higher education, respectively the quality of education is closely related to the training resources, ie. adequate funding must be provided [9].

Funding for higher education in Bulgaria lags behind the EU average. According to Eurostat [12] public expenditure on higher education in the EU-28 in 2017 amounted to $1.22 \%$ of GDP, while expenditure for educational institutions funding from public sources in the higher education network in Bulgaria amounted to only $0.81 \%$ of GDP, which is 1.5 times lower than the EU average. The highest public expenditure on higher education relative to GDP is reported in Denmark (2.45\% of GDP). 
Another key indicator that shows the level of public spending on higher education is the annual public spending per student. The average annual public expenditure per student in the EU-28 for 2017 is 10,305.3 euros according to Eurostat data [12]. The highest public expenditure per student in 2017 among EU Member States is incurred by Luxembourg (EUR 41,533.1), followed by Sweden (EUR 26,523.1); high levels of this indicator are observed in the Nordic countries Denmark (EUR 24,566.8) and Finland (EUR 16,180.7). The public costs per student in Bulgaria amount to EUR 2,080.9 / year. This is 5 times less than the European average and almost 20 times less than in Luxembourg. Expenditures in Romania (EUR 2,623.0) and Greece (EUR 1,481.0) are close to those in Bulgaria.

The comparison with the EU countries clearly shows that higher education in Bulgaria needs more financial support. Given that funding for higher education is limited within the available public resources, other sources of external funding should be sought. European funds and programs represent such an opportunity.

\section{A brief overview of higher education funding from the European Structural and Investment Funds}

After Bulgaria's accession to the EU, European funds and programs are the main external resource that all public authorities in our country, including the Bulgarian higher education, rely on. The importance of the operational programs for achieving sustainable growth in Bulgaria is indisputable and their management and implementation is crucial [13].

Bulgarian higher education institutions fall into the eligible category of beneficiaries of the operational programs during the programming periods 2007-2013 and 2014-2020. They receive support for the implementation of their projects through programs co-financed by the European Regional Development Fund (ERDF) and the European Social Fund (ESF).

During the 2007-2013 programming period, the main operational program under which Bulgarian universities were eligible beneficiaries was OP Human Resources Development. Within the program, more than 10 procedures for providing grants were launched, under which projects for strengthening the capacity and development of HEIs were financed. Under this program, support was received for the so-called "soft" projects.

Under OP Development of the Competitiveness of the Bulgarian Economy HEIs have received investment support for the creation and strengthening of the scientific infrastructure and transfer of innovations under two calls for project proposals.

Fifteen universities have benefited from support for the implementation of investment projects to improve the energy efficiency of university buildings and modernize the physical environment in libraries under OP Regional Development (OPRD).

During the 2007-2013 programming period, under all open calls for project proposals, except for the one under OPRD, where a territorial eligibility criterion was imposed, all HEIs had the opportunity to submit projects without restrictions. This approach enables the managing authorities to choose among a large number of submitted project proposals and to finance the best ones, which have received high points in the evaluation of their merits.

According to the Information System for Management and Monitoring of the EU Structural Instruments in Bulgaria [14] for the 2007-2013 programming period, there were a total of 267 implemented projects with higher schools as beneficiaries, at a total value of nearly BGN 109 million, of which the grants amount to BGN 106.5 million. This amount was paid to 43 beneficiary universities within the seven-year programming period and represents about $11 \%$ of the average annual expenditure on higher education for the same period.

During the 2014-2020 programming period, the Bulgarian higher education institutions were in the eligible categories of beneficiaries under three operational programs, having access to two of the funds of the Cohesion Policy (ERDF and ESF). 
The reference in the Information System for Management and Monitoring of EU Funds in Bulgaria 2020 [15] shows that during the 2014-2020 programming period several procedures were carried out for providing grants under these programs until May 2021, as a result of which 47 contracts were concluded with higher education institutions with a total value of nearly BGN 280 million. The average value of a project is just under BGN 6 million, and the beneficiaries of the contracts are a total of 27 higher education institutions.

Comparing the two programming periods we can draw the following conclusions:

1. During the second programming period, the planned European funds for the development of higher education are significantly higher and despite the fact that the implementation of the programming period has not ended, 2.5 times more funds agreed with HEIs (from BGN 109 million to BGN 280 million) are reported.

2. The number of universities implementing projects as beneficiaries has significantly decreased (from 43 to 27 ).

3. The number of implemented projects has decreased almost six times, respectively the average value of one project has risen sharply, from BGN 407 thousand to BGN 6 million.

The analysis the information about the higher schools which received the largest European funding during the two programming periods, the indicators of the number of funded projects and the amount of the agreed funds show the following significant differences:

1. Higher education institutions with proven capacity in the preparation and implementation of projects in the period 2007-2013 are not among the most active in the period 2014-2020, both in terms of the number of projects and on the basis of the agreed funds. Some of these universities are not beneficiaries under any project in the second period.

2. Significant differences are reported, both in the average value of the agreed funds for one project and in the total amount of the agreed European funding for one higher education institution. Given the principle of financing, namely the reimbursement of actual costs incurred by the beneficiary, the implementation of projects with such budgets is extremely challenging, as it requires significant financial capacity and free working capital.

3. Private higher education institutions are facing increasing difficulties in obtaining financial support from the operational programs for the implementation of their projects. It is difficult for them to find a place among the best for the period 2014-2020, as only one private university was implementing a project as a beneficiary in that period. For comparison, in the period 2007-2013, twelve out of a total of fourteen private HEIs received funding from the operational programs.

The main reason that can explain the differences in the state of European funding for higher education in Bulgaria during the two programming periods is the changed policy at the national level on the rules for providing grants under operational programs.

During the programming period 2021-2027 higher education institutions will also have the opportunity to implement projects under three programs. These are the Competitiveness and Innovation in Enterprises Program, the Research, Innovation and Digitalisation for Smart Transformation Program, co-financed by the ERDF and the Education Program, cofinanced by the ESF+ [16].

Since the programming process is not yet finished, it is difficult to say with certainty what the specific opportunities will be, but it is very likely that the planned financial resources for higher education will be greater than in previous programming periods. Under the Competitiveness and Innovation Program, universities will have the opportunity to partner with SMEs on projects implemented under the specific objective "Strengthening research and innovation capacity and the introduction of modern technologies" of the first priority of the program. The Research, Innovation and Digitalization Program for Smart Transformation is designed with two main priorities. Under the first priority, with an 
indicative budget of $€ 764$ million, higher education institutions are part of the target group. The education program is worth a total of $€ 751$ million in European funding from the European Social Fund, including measures in support of vocational and higher education, strengthening the links between them, the links with science and with the dynamic needs of the labor market under Priority 3 Linking education to the labor market ( $€ 314$ million). Various projects will support the introduction of dual education in higher education, vocational guidance of students through internships, revision and updating of curricula, etc.

\section{Research results and findings}

In order to determine the importance and role of grant funding from the Cohesion Policy funds for the development of higher education in Bulgaria, as well as the problems that accompany the preparation and implementation of projects, an interview was conducted with 10 experts, of whom: 2 academic researchers in the field of educational project implementation, 3 experts, representatives of public authorities and 5 experts with practical experience gained from their participation in many successfully completed projects.

Each expert answered the following five questions:

1.What is the impact of funding under the operational programmes for higher education in Bulgaria?

2.What are the direct effects (positive and negative) for the higher schools from the implementation of projects funded under the operational programmes?

3. What are the indirect effects (positive and negative) for the higher schools from the implementation of projects funded under the operational programs?

4. What is the main problem of project proposal funding and how it can be overcome?

5.What is the main problem of project implementation and how it can be overcome?

The results of the study are processed by content analysis and are presented in summary form in Table 1 and Table 2. 
Table 1. Effects of project funding in higher education

\begin{tabular}{|c|c|c|}
\hline & Direct effects & Indirect effects \\
\hline $\begin{array}{l}\text { Positive } \\
\text { effects }\end{array}$ & $\begin{array}{l}\text { - synchronization of the activities of } \\
\text { HEIs with the priorities and the goals } \\
\text { set out in national strategic documents } \\
\text { in the area of science and education } \\
\text { - improving the quality of the provided } \\
\text { educational service } \\
\text { - promotion of research and } \\
\text { implementation of innovations } \\
\text { - improving the competitiveness of } \\
\text { HEIs } \\
\text { - flexibility of HEIs and practical } \\
\text { orientation of their actions and } \\
\text { programs } \\
\text { - an additional source of funding }\end{array}$ & $\begin{array}{l}\text { - active work in a competitive } \\
\text { environment, especially in the procedures } \\
\text { of competitive selection of projects } \\
\text { - comparison with other HEIs and } \\
\text { obtaining an objective assessment of the } \\
\text { conditions and opportunities } \\
\text { - building and developing the } \\
\text { administrative capacity of HEIs } \\
\text { - building partnerships with other } \\
\text { universities, businesses and research } \\
\text { organizations } \\
\text { - multiplication of projects participation } \\
\text { - increasing the internationalization of } \\
\text { HEIs } \\
\text { - image boosting } \\
\text { - providing funding for activities for } \\
\text { which funds are not available in the HEIs } \\
\text { budgets }\end{array}$ \\
\hline $\begin{array}{l}\text { Negative } \\
\text { effects }\end{array}$ & $\begin{array}{l}\text { - focusing only on topics of priority for } \\
\text { the respective funding programs } \\
\text { - lost benefits from working on other } \\
\text { activities due to invested resources in } \\
\text { projects that have not received funding } \\
\text { - focusing on project financing and } \\
\text { neglecting the current activities of HEIs } \\
\text { - using part of the HEIs budgets to } \\
\text { provide co-financing and funds for } \\
\text { project implementation }\end{array}$ & $\begin{array}{l}\text { - wasting time administering project } \\
\text { development and the reporting process } \\
\text { - missed opportunities for the } \\
\text { implementation of other projects (in case } \\
\text { of limited capacity) }\end{array}$ \\
\hline
\end{tabular}

Source: Compiled by the author based on interviews with experts

Undoubtedly, grant funding, including within the operational programs, is of utmost importance for HEIs. It creates opportunities for development and leads to significant changes. Through the implementation of various projects the physical environment is improved and technological modernization of the higher schools is achieved, including improved scientific infrastructure. New teaching methods are introduced, the range of forms of educational activities is expanded, curricula are updated, experience is intensively shared and knowledge is transferred. The potential of HEIs for research work is developed and expanded, scientists are directly or indirectly supported in their research work. All this adds value to the services offered by HEIs and leads to an improvement in the quality of the educational service provided.

Regarding the nature of the impact of project funding on higher education, the prevailing opinion is that the positive effects outweigh the negative ones. There is unanimity concerning the specific manifestations of both positive and negative direct and indirect effects.

In order to maximize the positive effects of project funding, the existing problems outlined by the experts accompanying the preparation and implementation of projects should be minimized and some of the measures indicated by them can be applied. 
Table 2. Most significant problems of educational projects and measures to overcome

\begin{tabular}{|c|c|}
\hline \multicolumn{2}{|c|}{ 1. At the stage of project proposal development } \\
\hline Problems & Measures to overcome problems \\
\hline $\begin{array}{c}\text { - Low administrative capacity of HEIs } \\
\text { - Poor knowledge of European and national } \\
\text { rules regarding the specifics of funding } \\
\text { under operational programs } \\
\text { - Lack of desire to participate in projects } \\
\text { - Short deadlines for preparation of project } \\
\text { proposals and the need to provide a large } \\
\text { number of documents } \\
\text { - Difficulties in planning due to a significant } \\
\text { time lag between calls for applications } \\
\text { - Poor synchronization of funding } \\
\text { opportunities with existing problems } \\
\text { - Impossibility to submit projects under } \\
\text { some of the calls due to restrictions on the } \\
\text { eligibility of applicants }\end{array}$ & $\begin{array}{c}\text { - Trainings on writing project proposals } \\
\text { - Appropriate system of incentives at the level of } \\
\text { HEIs to motivate academic staff to participate in } \\
\text { project proposal writing } \\
\text { - Improving the internal system of HEIs in } \\
\text { connection with the preparation of project } \\
\text { proposals } \\
\text { - Limiting the number of documents } \\
\text { accompanying the project proposal } \\
\text { - Simplification of the application process, incl. } \\
\text { introduction of application in two stages } \\
\text { (conceptual and actual) } \\
\text { - Inclusion of information in the indicative work } \\
\text { programs for periods longer than one year } \\
\text { - Reprogramming of programs in the course of } \\
\text { their implementation }\end{array}$ \\
\hline \multicolumn{2}{|c|}{ 2. At the stage of implementation and reporting of financed projects } \\
\hline Problems & Measures to overcome problems \\
\hline $\begin{array}{l}\text { - Low administrative capacity of the teams } \\
\text { directly involved in the management of the } \\
\text { funded projects } \\
\text { - Complex administrative procedures and } \\
\text { project reporting requirements } \\
\text { - Poor interaction between HEIs and } \\
\text { Managing autorities of the programmes } \\
\text { - Delay in the recovery of verified amounts } \\
\text { - Difficulties in conducting procedures for } \\
\text { selection of contractors } \\
\text { - Imposition of financial adjustments during } \\
\text { and after the projects implementation } \\
\text { - Difficulties in implementation due to lack } \\
\text { of free working capital }\end{array}$ & $\begin{array}{c}\text { - Specific trainings on project management, } \\
\text { organized and conducted by the financing bodies } \\
\text { - Assistance to project implementation teams by } \\
\text { managing authorities } \\
\text { - More active involvement of HEI representatives } \\
\text { in the programs' bodies } \\
\text { - Revision of the legally regulated verification } \\
\text { procedures and deadlines } \\
\text { - Preparation of standard documentation for } \\
\text { participation in tender procedures to be provided } \\
\text { to the beneficiaries }\end{array}$ \\
\hline
\end{tabular}

Source: Compiled by the author based on interviews with experts

Given the activity of higher education institutions in the previous two programming periods, briefly presented above, it can be concluded that despite the existing difficulties, they are aware of the opportunities provided by project funding and make the most of it. It can be expected that in the 2021-2027 programming period the trend will continue, even increasing the need for implementation of projects not only under the programs financed by the Cohesion Policy funds.

\section{Conclusions and recommendations}

The results of the scientific literature review, the analysis of secondary data and the qualitative research carried out justify the following conclusions:

- Financing of higher education institutions in this country seriously lags behind that of the developed EU member states, which can be mentioned as one of the factors for the lower quality of higher education.

- During the previous two programming periods, higher education institutions have accumulated significant capacity, which should be used in the next programming period $2021-2027$. 
- The study on grant funding has shown that it is assessed as an important tool for improving the quality of higher education and for the co-financing of higher education.

- It is recommended that the indicated positive direct and indirect effects of the project financing at the higher education level be taken into account.

- In order to improve the efficiency of project financing at the level of higher education, some of the measures for overcoming the problems accompanying the realization of the projects can be studied in detail and applied.

- It is necessary to stimulate the activity of the academic staff by creating permanent and temporary teams to participate in the preparation and implementation of projects with European funding.

\section{References}

1. M. Ivanova, Sastoyanie na vnedryavaneto na inovatsiite $\mathrm{v}$ stroitelnite predpriyatia $\mathrm{v}$ Bulgaria, Izvestia, 3, 102-114 (2012)

2. K. Antonova, Konkurentna sposobnost na organzatsiite chrez strategichesko upravenie na znaniyata, Izvestia, 2, 99-102 (2013)

3. A. Petkov, A. Nedyalkov, M. Boneva, Izsledvane na sistemi za otsenka na kachestvoto vav vissheto obrazovanie, in Proceedings of IX International Scientific Conference "EGovernance and E-Communications", 99-108 (2017)

4. D. Dimitrova, Aktove na organite za upravlenie na visshite uchilishta, (Varna: Nauka i ikonomika, 2021)

5. D. Dimitrova, Pravni aspekti na stopanskata deynost na darzhavnite visshi uchilishta, Rolyata na pravoto v savrennata ikonomika, 127-137 (2017)

6. Е. Bennetot, A. Claeys-Kulik и Т. Estermann, Designing Strategies for Efficient Funding of Universities in Europe, Brussels: European University Association (2015)

7. K. Marsikova, V. Urbanek, Investment in Education: Earnings and Returns, (Liberec: Technická univerzita v Liberci, 2013)

8. I. Zhelev, S. Hristova, Evropeyskite fondove i finansiraneto na vissheto obrazovnie v Bulgaria, Strategii na obrazovatelnata i nauchnata politika, 28(3), 223-236 (2020)

9. A. Vutsova, M. Arabadzhieva, Kachestvo na vissheto obrazvonie v Bulgaria v konteksta na Evroeyskoto prostranstvo za visshe obrazvonie - problemi i vazmzhni reshenia, Strategii na obrazovatelnata i nauchnata politika, 24(4), 351-361 (2016)

10. Strategia za razvitie na vissheto obrazovnie v Bulgaria za peiroda 2014-2020, (2015), [Online], https://www.mon.bg/bg/143, [Accessed: 26 May 2021]

11. Strategia za razvitie na vissheto obrazovnie v Bulgaria za peiroda 2021-2030, (2021), [Online], https://www.mon.bg/bg/143, [Accessed: 26 May 2021]

12. Eurostat, Educational expenditure statistics“, [Online], http://ec.europa.eu/eurostat/, [Accessed: 23 May 2021]

13. V. Kurshumov, Upravlenie i ustoychivo razvitie, 62(1), 78-83 (2017)

14. UMIS, Unified Management Information System for the EU Structural Instruments in Bulgaria, [Online], http://umispublic.government.bg/, [Accessed: 23 May 2021]

15. ISUN, Information System for Management and Monitoring of EU Funds in Bulgaria 2020, [Online], https://eumis2020.government.bg/, [Accessed: 23 May 2021]

16. Informational portal, European structural and investmat funds in Bulgaria, [Online], https://www.eufunds.bg/bg, [Accessed: 24 May 2021] 